\title{
Posidonia oceanica as thermal insulation: Determination of the minimum bulk density, according to project specifications, for its use as a building solution on a flat roof
}

\section{Posidonia oceanica como aislamiento térmico: Determinación de la densidad aparente mínima, según requisitos de proyecto, para su utilización como solución constructiva en cubierta plana}

Cristian Carmona (Main and Corresponding Author)

Departamento de Física, Universidad de las Islas Baleares

Cra. Valldemossa km 7.5, 07122 Palma, Islas Baleares (Spain)

cristian.carmona@uib.es

\section{Gabriel Horrach}

Departamento de Física, Universidad de las Islas Baleares Cra. Valldemossa km 7.5, 07122 Palma, Islas Baleares (Spain)

gabriel.horrach@uib.es

\section{Carles Oliver}

Instituto Balear de la Vivienda, Departamento Técnico

C. de Manuel Azaña 9, 07006 Palma, Islas Baleares (Spain)

cgoliver@ibavi.caib.es

\section{Francisco J. Forteza}

Departamento de Física, Universidad de las Islas Baleares Cra. Valldemossa km 7.5, 07122 Palma, Islas Baleares (Spain) francisco.forteza@uib.es

\section{Joan Muñoz}

Departamento de Física, Universidad de las Islas Baleares Cra. Valldemossa km 7.5, 07122 Palma, Islas Baleares (Spain) joan.munoz@uib.es

\section{Manuscript Code: 948}

Date of Acceptance/Reception: 19.06.2018/27.07.2017

DOI: $10.7764 / R D L C .17 .2 .250$

\section{Abstract}

The Balearic Islands' Housing Institute (Instituto Balear de la Vivienda-IBAVI), in collaboration with the Directorate General of Nature, Environmental Education, and Climate Change of the government of the Balearic Islands, has received a European grant worth $€ 754,012$ from the LIFE +2012 program to carry out the building and monitoring of 14 public housing units in Sant Ferran, Formentera. The main objective of the project is to contribute to the development of technologies, methods, and innovative instruments in the field of nature conservation, climate change, environmental policy, the production of information, and communication on environmental issues in all EU member states. This paper, a collaborative effort between the University of the Balearic Islands and the IBAVI, presents the results obtained for the determination of the bulk density of a layer of Posidonia oceanica used as an insulating material, and which complied with the limitations of thermal conductivity for a thermal insulation solution in a flat roof.

Key words: thermal characterization, transmittance, roof, Posidonia oceanica, energy.

\section{Resumen}

El Instituto Balear de la Vivienda (IBAVI), en colaboración con la Dirección General de Medio Natural, Educación ambiental y Cambio Climático del Gobierno de las Illes Balears, ha recibido una subvención Europea valorada en 754,012€ del programa LIFE+2012, para llevar a cabo la construcción y monitorización del proyecto de 14 viviendas de protección pública en Sant Ferran, Formentera. El principal objetivo del proyecto es contribuir al desarrollo de tecnologías, métodos e instrumentos innovadores en el ámbito de la conservación de la naturaleza, el cambio climático, la política medioambiental y la información y comunicación sobre cuestiones medioambientales en todos los estados miembros de la UE. El presente artículo, colaboración entre la Universitat de les Illes Balears y el IBAVI, presenta los resultados obtenidos para la determinación de la densidad de una capa de Posidonia Oceánica utilizada como material de aislamiento, que cumpla las limitaciones de conductividad térmica de una solución de aislamiento térmico en cubierta plana. 
The project outlined in this study focuses on a set of buildings on the island of Formentera (Figure 1) in which the actual construction of the buildings and the buildings themselves should be the result of an exhaustive and rigorous study of the project and the conditions of the area. It includes a climatological study; mapping of available resources such as rainfall, geotechnics, morphology, the urban backdrop, and municipal ordinances; and all of the measures possible for minimizing the ecological footprint of the buildings both in their construction and their operational lifetime, via, for example, the use of local materials, existing nearby industry, traditional local building methods, and available renewable energies. All of this is considered in the context of optimizing the use of the building, maximizing sunlight, providing for the needs of residents, and minimizing energy consumption for heating and cooling the dwellings.

Figure 1. Location (Formentera, Balearic Islands, Spain) and model of the set of proposed buildings. Source: taken from http://reusingposidonia.com/proyecto-14hpp-sant-ferran

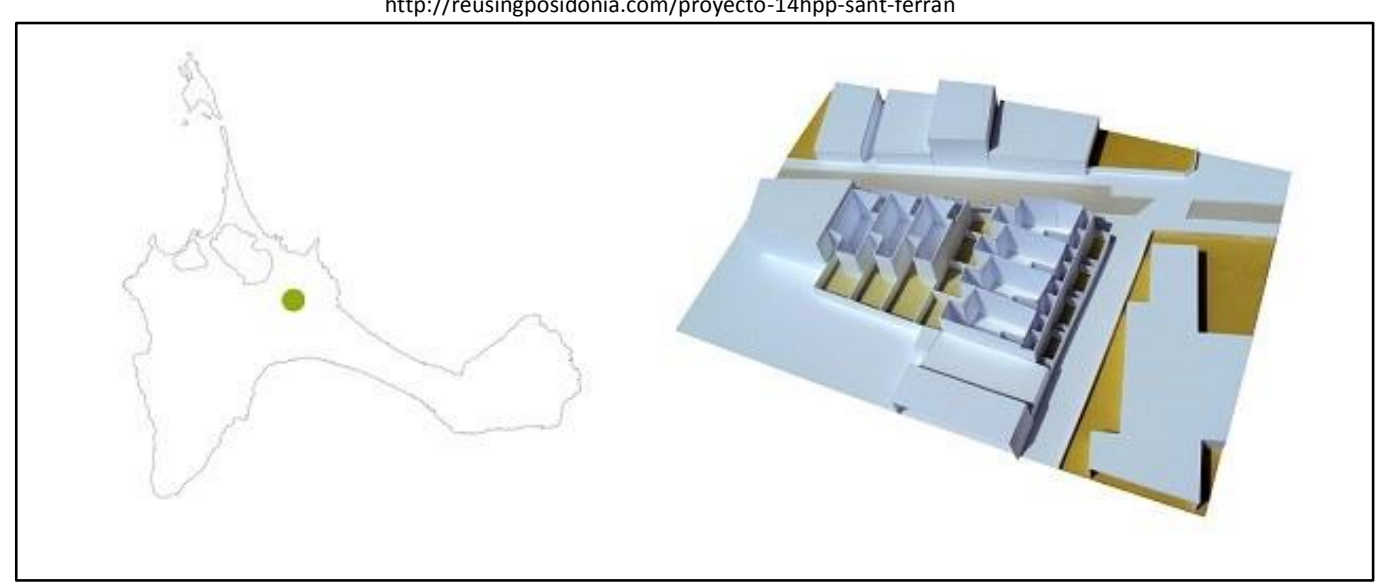

\section{Description of the problem}

For this project, traditional architecture served as a reference for how to work with scarce resources. A study was carried out to determine which resources available on the island of Formentera (Balearic Islands, Spain) could be used in the construction of the buildings. The Phoenician juniper (Juniperus Phoenicea), which was once commonly used for floor joists (Ruiz-Checa \& Cristini, 2013) is now a protected species (List, 2004). Limestone quarries have been depleted (BOIB, 2004), and the little straw that is produced is used for livestock. So, the only resource that is left comes from the sea: Posidonia oceanica (commonly known as Posidonia), an aquatic plant with narrow ribbon-like leaves that can reach up to 1.5 meters in length. They stretch out in dense meadows, provide protection to fauna, and soften the power of currents and waves (Infantes et al., 2012).

Thus, instead of investing in chemical-based industries located more than 1,000 kilometers away, we propose focusing the same budget on local labor which can be used to lay the Posidonia out to dry in the sun and compact it to a certain density on rooves. Furthermore, the sea salt in the Posidonia serves as a natural biocide (Gobert et al., 2007; Sasso et al., 2013).

The consideration for which materials would be used for the rest of the building was derived from a market study that incorporated financial costs, embedded $\mathrm{CO}_{2}$ (Hammond \& Jones, 2008), the materials' ability to provide a suitable level of comfort in a passive dwelling (Rawi \& Al-Anbuky, 2009) and promotion of life cycle thinking in the construction industry (Gonçalves de Lassio \& Naked Haddad, 2016).

State of the art

The use of Posidonia oceanica as an insulator is suggested as a solution for transitable rooftops as it maximizes efficiency while minimizing projected costs (Fargallo, Alés, \& Rodríguez, 2015). In the case at hand, the Posidonia was dried during the months of July and August in 2014, in order to take advantage of a period of inactivity as determined by Formentera's police and government ordinances (BOIB, 2015). This process involved spreading the material out in thin layers of 0.05-0.1 meters (Figure 2) that were left out in the sun for one full day so that once dried it could be stored in a place where it would be protected from rain and moisture until it was to be used. 
Figure 2. Spreading out the Posidonia oceanica. Source: taken from

http://reusingposidonia.com/construccion-del-prototipo

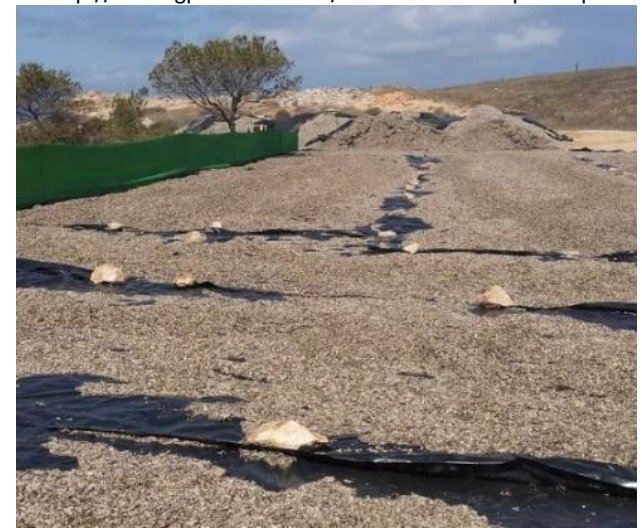

In order to begin the process of installing the Posidonia as thermal insulation (Figure 3), the structure of the ceiling first had to be built. Then recycled construction pallets were placed upside down and stuffed with the Posidonia. The pallets were positioned on top of sloped lightweight concrete which itself was lined on the bottom with a sheet of waterproof polyethylene.

Figure 3. From right to left and top to bottom; positioning of the pallets on the waterproof sheet so they can be filled with the Posidonia; Filled with compacted Posidonia; Installation of the wooden boards (OSB/3) for containing the Posidonia; Final appearance of the finished rooftop; Source: taken from
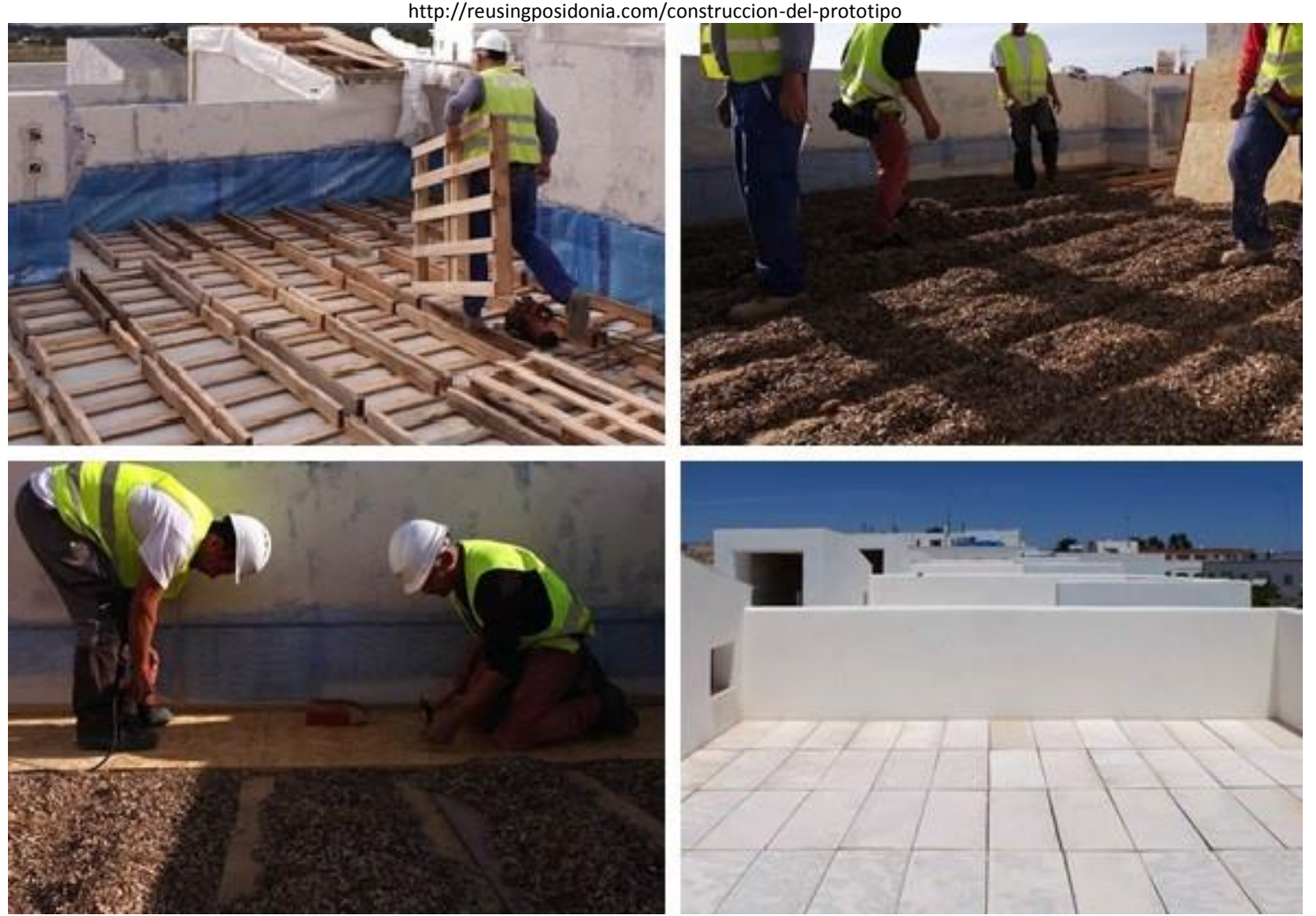

The Posidonia was then distributed over $500 \mathrm{~m}^{2}$ of rooftop. It was manually compacted into the recycled construction pallets to reach a minimum density of $185 \mathrm{~kg} / \mathrm{m}^{3}$ : a value that is justified in the present article.

While the roof was being built, the compacted area was covered with plastic (polyethylene) at the end of every workday in order to prevent possible problems from dew, wind, or rain. Once the compacting was finished and everything was dried, OSB wooden boards (BSI, 2006) were fixed to the crossbars of the pallets with galvanized bolts.

A layer of geotextile was then installed over the horizontal surface of the boards to protect the waterproofing layer of $\operatorname{EPDM}(\mathrm{BSI}, 2014)$ which was fastened on the sides and bonded to the first waterproof layer of polyethylene (under the sloped concrete). The joining of the underlying polyethylene sheet and the upper layer of EPDM guaranteed a watertight seal of the interior chamber, a constant level of moisture of the Posidonia, and the maintenance of its insulating 
properties. Thus this system depends on the perfect watertight sealing of the layers; in Figure 4 there is a detailed cross section of the final roof.

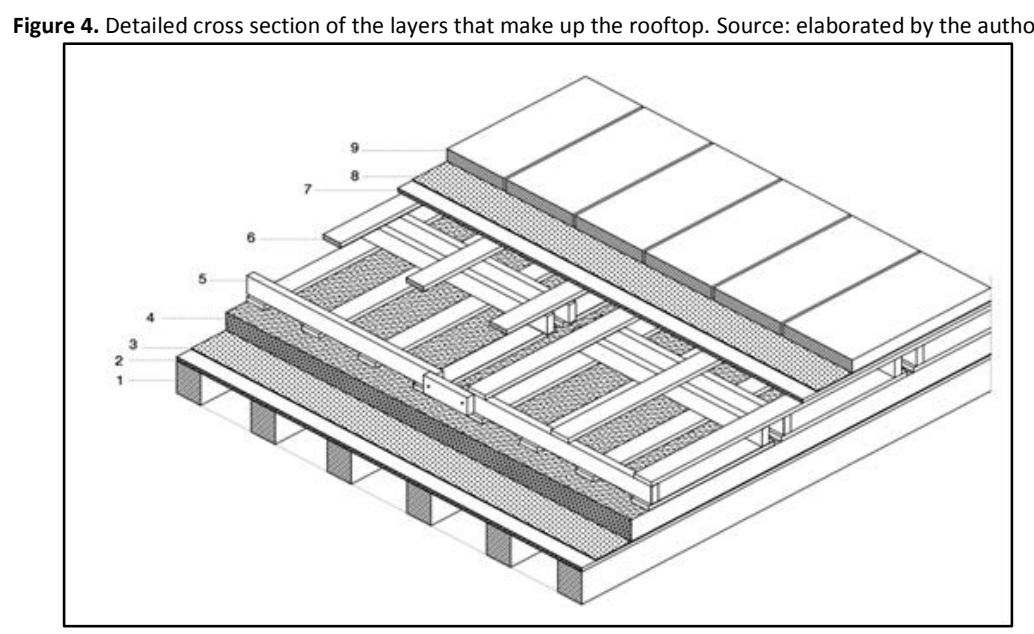

- $\quad$ Layer 1, GL24-style laminated wooden beams

- $\quad$ Layer 2, OSB/3 board

- Layer 3, Riwega USB-style breathable waterproof polyethylene sheet

- Layer 4, HC-250 kg/m $\mathrm{m}^{3}$ aerated concrete to create slopes

- Layer 5, Dry Posidonia oceanica compacted on site to $15 \mathrm{~cm}$ layer

- Layer $6,5 \times 10 \mathrm{~cm}$ wooden strips

- Layer 7, OSB/3 board

- $\quad$ Layer 8, Waterproof EPDM sheet + geotextile

- Layer 9, Top quality, locally sourced limestone ashlars (marés de Ca's Busso)

\section{Methodology}

Collaborative efforts between the Balearic Islands' Housing Institute (IBAVI) and the University of the Balearic Islands (UIB) were set up to determine the thermal conductivity of a layer of Posidonia at a specified density and thickness. Requirements imposed by the technical building codes (CTE DB-HE by their Spanish acronym) were always considered, as were the requirements for the building to achieve an " $A$ " level energy rating (Fomento, 2013).

These two prerequisites placed restrictions on the maximum thermal transmittance that could be allowed for the Posidonia-based layer of insulation. The CTE DB-HE, in their chart for characteristic E1 parameters, recommends a thermal transmittance value for rooves of no more than $0.33 \mathrm{~W} / \mathrm{m}^{2 *} \mathrm{~K}$. Knowing the composition, thermal conductivity of the materials $(\lambda)$, and the thickness $(e)$ of each layer that would have an impact on the final thermal transmittance of the building solution (as can be seen in Table 1) we were able to determine the maximum value of conductivity of the insulating material.

\begin{tabular}{ccc}
\multicolumn{4}{c}{ Table 1. Thermal characteristics of the layers of building elements. Source: elaborated by the authors. } \\
\hline Material of layer & $\mathrm{e}(\mathrm{m})$ & $\lambda\left(\mathrm{W} / \mathrm{m}^{*} \mathrm{~K}\right)$ \\
\hline OSB $\mathrm{d}<650$ & 0.018 & 0.13 \\
Autoclaved cellular concrete & 0.08 & 2 \\
Posidonia oceanica insulation & 0.15 & To be determined \\
OSB 450 $<\mathrm{d}<650$ & 0.018 & 0.15 \\
Limestone $1700<\mathrm{d}<2200$ & 0.07 & 3 \\
\hline
\end{tabular}

In line with the most restrictive limit placed on the building project, the maximum thermal transmittance value for rooves for this study was $0.22 \mathrm{~W} / \mathrm{m}^{2 *} \mathrm{~K}$. Equation (1) shows the thermal relationship between conductivity, $\lambda$; thermal resistance, $R$; and thermal transmittance, $U$, where $e$ is the thickness of the sample being analyzed.

$U=\frac{1}{R}\left(\frac{\boldsymbol{m}^{2} * \stackrel{\mathrm{o}}{ } \boldsymbol{K}}{W}\right) ; R=\frac{e}{\lambda}\left(\frac{\boldsymbol{m}^{2} * \stackrel{\circ}{K}}{W}\right) ; U=\frac{\lambda}{e}\left(\frac{W}{\boldsymbol{m}^{2} * \stackrel{\circ}{ } K}\right)$ 
Equation (2) shows the relationship between the thermal resistances of the various layers of materials as well as the thermal resistance of contact with the environment. In this equation, $R p$ is the minimum thermal resistance required by the project $\left(4.54 \mathrm{~m}^{2 *} \mathrm{~K} / \mathrm{W}\right)$, Rpos is the thermal resistance of the layer of Posidonia, $R s i$ is the thermal resistance of contact with the interior environment $\left(0.1 \mathrm{~m}^{2 *} \mathrm{~K} / \mathrm{W}\right)$, Rse is the thermal resistance of contact with the external environment $\left(0.04 \mathrm{~m}^{2 *} \mathrm{~K} / \mathrm{W}\right)$, and $R n$ is the thermal resistance of the other known materials.

$R p<R s i+R p o s+\sum R n+R s e$

Knowing the relationship between these resistances, the thermal resistance minimum $\left(4.54 \mathrm{~m}^{2 *} \mathrm{~K} / \mathrm{W}\right)$, the values of $R s e$ $\left(0.04 \mathrm{~m}^{2 *} \mathrm{~K} / \mathrm{W}\right)$ and $R s i\left(0.1 \mathrm{~m}^{2 *} \mathrm{~K} / \mathrm{W}\right)$, as well as the value of thermal resistance of the rest of the materials $(1.07$ $\left.\mathrm{m}^{2 *} \mathrm{~K} / \mathrm{W}\right)$, we were able to determine the minimum thermal resistance of the layer of Posidonia oceanica: Rpos $=3.33$ $\mathrm{m}^{2 *} \mathrm{~K} / \mathrm{W}$. At the same time, knowing the thickness of the layer of insulation $(0.15 \mathrm{~m})$, we were able to obtain a value of maximum thermal conductivity that the layer of Posidonia could reach: $0.045 \mathrm{~W} / \mathrm{m}^{*} \mathrm{~K}$.

After determining the maximum thermal conductivity of the Posidonia, we proceeded to see if it was possible to obtain such levels in practice and what density would be necessary to do so. Due to the heterogeneity of the components in this biological material and the variability in samples coming from differing locations, we could not establish the characteristics of the Posidonia using methodologies based on homogeneous layers (BSI, 2007a). To solve this problem, we carried out an analysis on samples collected from the area where the plants were dried using the hot box method of characterization described in multiple regulations (BSI, 1996; International, 2014; GOST, 2000).

The hot box instrumentation systems were based on two techniques. The first, established by ISO and ASTM standards (BSI, 1996; International, 2014), utilizes a guarded chamber and involves exposing the sample to two predefined temperatures. The thermal resistance of the sample is determined by the quantity of energy required to keep both temperatures constant. The second technique, defined in the GOST standard (GOST, 2000), is known as the calibrated hot box methodology, and it involves exposing the sample to two stable temperatures and establishing transmittance by measuring the heat flux that goes through the sample.

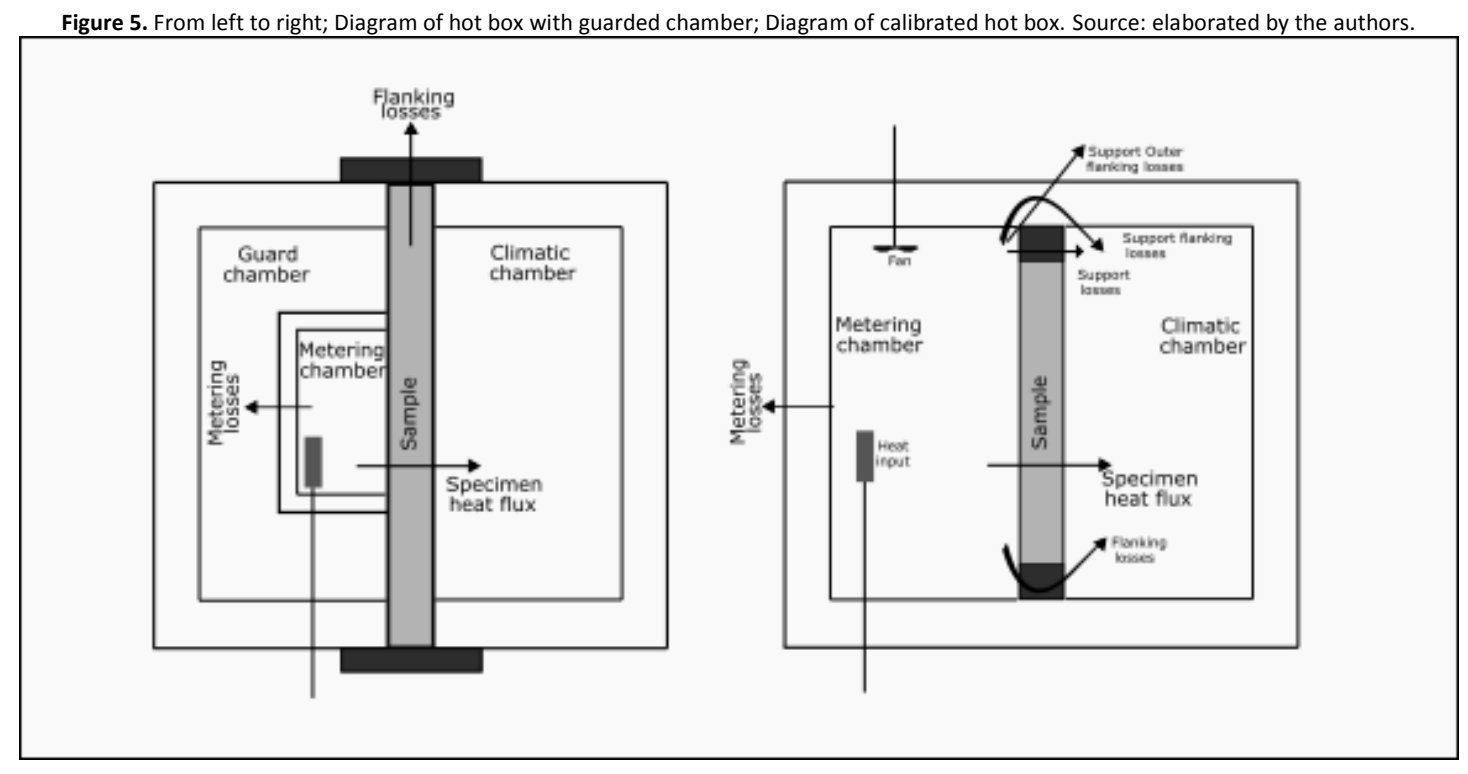

In both the hot box with the guarded chamber and the calibrated hot box methodologies, it is necessary to carefully monitor how much of the supplied energy is transmitted through the sample compared to how much is lost to the outside environment. Exterior losses depend on the method used and could be the result of loss coming exclusively from the instrument, or they could be the result of losses coming from transmission from the material to the external environment, as can be seen in Figure 5.

For this project, the calibrated hot box methodology was utilized. To do this, a hot plate was placed in the area below a sample, as can be seen in Figure 6, and we analyzed the stable temperature gradient between the areas above and below the sample. 
Figure 6. Calibrated hot box diagram, like the one that was used in the experiment. Source: elaborated by the authors.

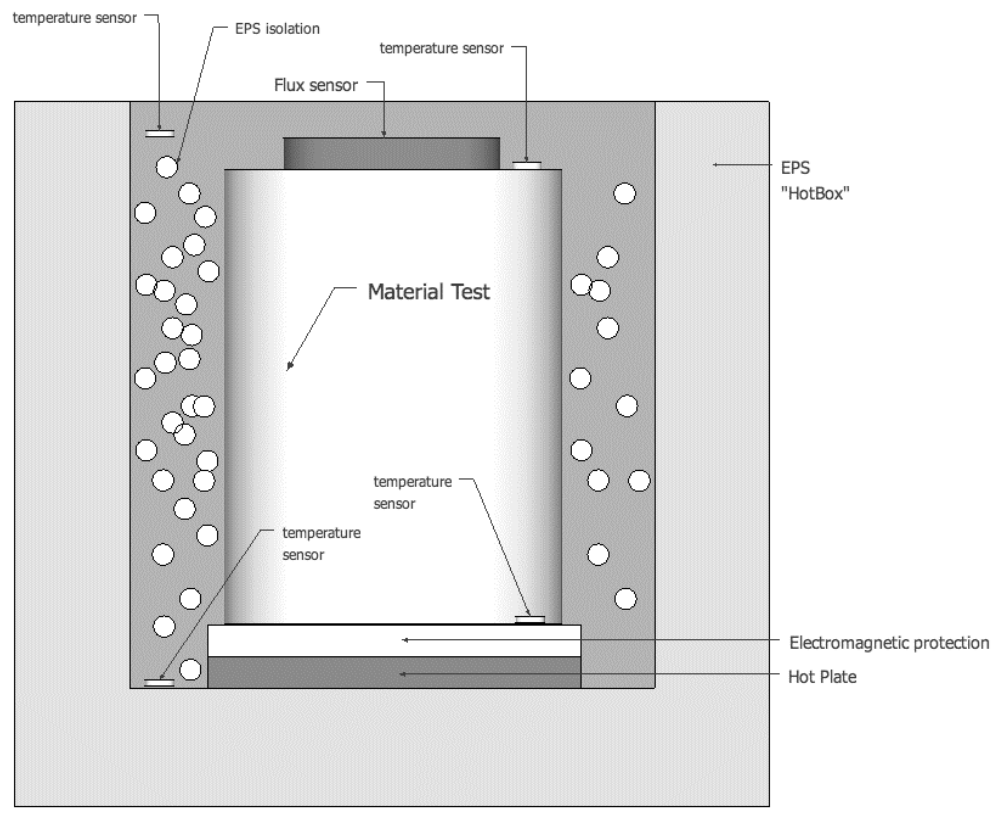

The layer of Posidonia was analyzed by considering various different samples (cylindrical test tubes, $0.12 \mathrm{~m}$ in diameter, $0.125 \mathrm{~m}$ in height) with a range of densities which allowed us to define the target density by thermal conductivity. Initially, three densities were analyzed in order to establish a representative range of thermal densities that could be reached; the densities ranged from a minimum of $150 \mathrm{~kg} / \mathrm{m}^{3}$ to a maximum of $250 \mathrm{~kg} / \mathrm{m}^{3}$. All density values that were used were calculated as bulk densities from geometric volume.

Table 2. Thermal conductivity values. Source: elaborated by the authors.
\begin{tabular}{cc} 
Density $\left(\mathrm{kg} / \mathrm{m}^{3}\right)$ & $\begin{array}{c}\text { Thermal } \\
\text { conductivity } \\
\text { (W/m*K) }\end{array}$ \\
\hline 150 & 0.049 \\
200 & 0.043 \\
250 & 0.039 \\
\hline
\end{tabular}

As shown in Table 2, the thermal conductivity values that were obtained indicate that the density needed to reach the target conductivity in the building application being studied should be between the $150-200 \mathrm{~kg} / \mathrm{m}^{3}$.

Once the range containing the target density was found, two additional samples were prepared. In this case, the samples were lined with the same waterproof EPDM sheet that would later be used in the actual building. In this way, we could also see how the Posidonia would behave when facing with increased temperatures in a situation where residual humidity had no place to escape.

Table 3. Thermal conductivity results. Source: elaborated by the authors.
\begin{tabular}{cc} 
Density $\left(\mathrm{kg} / \mathrm{m}^{3}\right)$ & $\begin{array}{c}\text { Thermal } \\
\text { conductivity } \\
\text { (W/m*K) }\end{array}$ \\
\hline 185 & 0.044 \\
215 & 0.041 \\
\hline
\end{tabular}

Table 3 shows the results of a test of two samples: one at $185 \mathrm{~kg} / \mathrm{m}^{3}$ in which the desired density was achieved via manual compacting of the Posidonia, and another with a density of $215 \mathrm{~kg} / \mathrm{m}^{3}$ that was compacted mechanically (with weight). 
The projected and applied solution, a layer of thermal insulation made out of Posidonia oceanica at a density of 185 $\mathrm{kg} / \mathrm{m}^{3}$, guaranteed a thermal conductivity of $\lambda=0.044 \mathrm{~W} / \mathrm{m} * \mathrm{~K}$, and thus met the thermal transmittance requirements established by the project. There is even the possibility to improve this conductivity by using the Posidonia at a density of $215 \mathrm{~kg} / \mathrm{m}^{3}$ to give $\lambda=0.041 \mathrm{~W} / \mathrm{m}^{*} \mathrm{~K}$. Regarding the solution that was employed, the results are comparable with those that are offered by synthetic insulation solutions like EPS (expanded polystyrene) (BSI, 2007b) with a density of between 40 and $50 \mathrm{~kg} / \mathrm{m}^{3}$ and $\mathrm{a} \lambda=0.042 \mathrm{~W} / \mathrm{m}^{*} \mathrm{~K}$.

It is worth nothing that, with respect to the densities described, to achieve the maximum level of thermal insulation with the thinnest building profile, the weight of the Posidonia-based solution would be on the order of three to four times greater than a solution based on EPS. Structurally, the difference in weight would not lead to problems as the order of magnitude of the difference of the weights per square meter between the two materials is totally able to be supported by the structures that are commonly built as residences (Fomento, 2009).

Finally, the results that we obtained ensure that Posidonia will used as a thermal insulation element in building solutions for flat transitable roofs. Using equations (1) and (2) with the value of conductivity that was obtained, transmittance, $U$, of the building component was $0.216 \mathrm{~W} / \mathrm{m}^{2 *} \mathrm{~K}$ with a layer of Posidonia at a density of $185 \mathrm{~kg} / \mathrm{m}^{3}$. This value of thermal transmittance meets both the demands of the project itself, which aimed to improve energy efficiency $U<0.22 \mathrm{~W} / \mathrm{m}^{2 *} \mathrm{~K}$ (Oliver, 2012), and of the technical building code, recommended $U<0.33 \mathrm{~W} / \mathrm{m}^{2 *} \mathrm{~K}$ (Fomento, 2013).

References

BOIB. Sección II -Consejos Insulares (2004). Retrieved from http://www.conselldemallorca.net/media/21472/Acuerdo_Pleno_PTM_2004.pdf

BOIB. BOIB Núm. 066 - 30/Abril/2015, BOIB $\S \quad$ (2015). Retrieved from http://www.caib.es/eboibfront/es/2015/10291/seccion-iii-otras-disposiciones-y-actosadministra/472

BSI. (1996). BS EN ISO 8990:1996 Thermal insulation - Determination of steady-state thermal transmission properties - Calibrated and guarded hot box, BSI § (1996). Retrieved from https://www.iso.org/standard/16519.html

BSI. (2006). BS EN 300:2006 - Oriented strand boards (OSB). Definitions, classification and specifications, British Standards Institute $\S$ (2006). Retrieved from http://shop.bsigroup.com/ProductDetail/?pid=000000000030113726

BSI. (2007a). BS EN ISO 6946:2007 - Building components and building elements. Thermal resistance and thermal transmittance. Calculation method, British Standards Institution $\S$ (2007). https://doi.org/10.3403/30127651

BSI. (2007b). BS EN 14933:2007 - Thermal insulation and light weight fill products for civil engineering applications. Factory made products of expanded polystyrene (EPS). Specification BSI British Standards, British Standards Institute $\S$ (2007). Retrieved from http://shop.bsigroup.com/ProductDetail/?pid=000000000030113506

BSI. (2014). BS ISO 4097:2014 - Rubber, ethylene-propylene-diene (EPDM). Evaluation procedure (2014). Retrieved from http://shop.bsigroup.com/ProductDetail/?pid=000000000030255647

Fargallo, A.P., Alés, V.F., \& Rodríguez, J.M.C. (2015). Comparison of energy-saving restoration costs based on Spain's initial constraints [single-family zone B4]. Revista de la Construcción 14(2):4450. https://doi.org/10.4067/S0718-915X2015000200006. 
Fomento, M. de. (2009). CTE-SE-M-Seguridad estructural Madera. Boletín Oficial Del Estado, 1-126. Retrieved

https://www.codigotecnico.org/images/stories/pdf/seguridadEstructural/DBSE-M.pdf

Fomento, M. de. (2013). Documento básico HE ahorro de energía §. Retrieved from http://www.codigotecnico.org/web/recursos/documentos/

Gobert, S., Cambridge, M.T., Velimirov, B., Pergent, G., Lepoint, G., Bouquegneau, J.-M., Walker, D.I. (2007). Biology of Posidonia. In Seagrasses: Biology, Ecologyand Conservation (pp. 387-408). Dordrecht: Springer Netherlands. https://doi.org/10.1007/978-1-4020-2983-7_17

Gonçalves de Lassio, J.G., \& Naked Haddad, A. (2016). Life cycle assessment of building construction materials: case study for a housing complex. Revista de la Construcción 15(2):69-77. https://doi.org/10.4067/S0718-915X2016000200007

GOST (2000). Gost 26602.1-99, Russian Standards and Regulations §. Retrieved from https://runorm.com/product/view/7/12038

Hammond, G.P., \& Jones, C.I. (2008). Embodied energy and carbon in construction materials. Proceedings of the Institution of Civil Engineers - Energy, 161: 87-98. https://doi.org/10.1680/ener.2008.161.2.87

Infantes, E., Orfila, A., Simarro, G., Terrados, J., Luhar, M., \& Nepf, H. (2012). Effect of a seagrass (Posidonia oceanica) meadow on wave propagation. Marine Ecology Progress Series 456: 63-72. https://doi.org/10.3354/meps09754

International, A. (2014). ASTM C1363 - 11 Standard Test Method for Thermal Performance of Building Materials and Envelope Assemblies by Means of a Hot Box Apparatus 1. American Society for Testing Materials, 90(Reapproved), 1-44. https://doi.org/10.1520/C1363-11.2

List, I. (2004). IUCN red list of threatened species. Retrieved from http://tienganhchuyennganh.webs.com/IUCN RED LIST OF THREATENED SPECIES.pdf

Oliver, C. (2012). LIFE REUSING POSIDONIA - 14 sustainable dwellings using local resources as Posidonia plants, at the Social Housing Development in Formentera. LIFE12 ENV/ES/000079. Retrieved May 16, 2017, from http://ec.europa.eu/environment/life/project/Projects/index.cfm?fuseaction=search.dspPage \&n_proj_id $=4647$

Rawi, M.I.M., \& Al-Anbuky, A. (2009). Passive house sensor networks: Human centric thermal comfort concept. ISSNIP 2009 - Proceedings of 2009 5th International Conference on Intelligent Sensors, Sensor Networks and Information Processing, 255-260. https://doi.org/10.1109/ISSNIP.2009.5416746

Ruiz-Checa, J.R., \& Cristini, V. (2013). Juniper Structures in Western Mediterranean Vernacular Architecture: Ongoing Research. Advanced Materials Research, 778:183-190. https://doi.org/10.4028/www.scientific.net/AMR.778.183

Sasso, S., Scrano, L., Ventrella, E., Bonomo, M. G., Crescenzi, A., \& Bufo, S. A. (2013). Natural biocides to prevent the microbial growth on cultural he- ritage. Built Heritage 1:1035-1042. Retrieved from http://www.bh2013.polimi.it/papers/bh2013_paper_150.pdf 